\title{
STUDY OF THERMOCYCLING EFFECT ON THE BOND STRENGTH BETWEEN AN ALUMINOUS CERAMIC AND A RESIN CEMENT
}

\author{
ESTUDO DO EFEITO DA CICLAGEM TÉRMICA NA RESISTÊNCIA DA UNIÃO ADESIVA \\ ENTRE UMA CERÂMICA ALUMINIZADA E UM CIMENTO RESINOSO
}

\author{
Osvaldo Daniel ANDREATTA FILHO ${ }^{1}$, Maria Auxiliadora Junho de ARAÚJO², Marco Antonio BOTTINO² \\ Renato Sussumu NISHIOKA ${ }^{3}$, Marcia Maciel MENEZES ${ }^{4}$
}

\author{
1- DDS, MSc, PhD, Graduate student (Doctor degree), Department of Dental Materials and Prosthodontics, FOSJC/UNESP. \\ 2- DDS, MSc, PhD, Associate Professor, Department of Dental Materials and Prosthodontics, FOSJC/UNESP. \\ 3- DDS, MSc, PhD, Assistant Professor, Department of Dental Materials and Prosthodontics, FOSJC/UNESP. \\ 4- DDS, MSc, PhD, Graduate student (Doctor degree), Department of Restorative Dentistry, FOSJC/UNESP. \\ Corresponding address: Osvaldo Daniel Andreatta Filho - Av. Coronel Alcântara, Centro. - Caçapava - SP Cep: 12281-580 \\ E-mail: danielunesp@ig.com.br
}

Received: March 3, 2004 - Modificaton: April 30, 2004 - Accepted: September 9, 2004

\begin{abstract}
$T_{\text {his }}$ resin cement (Panavia F, Kuraray CO). Nine ceramic blocks with dimensions of 5x6x6mm were conditioned at one face with Rocatec System (Espe). After, they were luted with Panavia F to composite resin blocks (Clearfil AP-X, Kuraray CO). The nine groups formed by ceramic, cement and composite resin were split up obtaining 75 samples with dimensions of $12 x 1 \times 1 \mathrm{~mm}$ and adhesive surface presenting $1 \mathrm{~mm}^{2} \pm 0.1 \mathrm{~mm}^{2}$ of area. The samples were divided into 3 groups (n=25): G1 - 14 days in distilled water at $37^{\circ} \mathrm{C}$; $\mathrm{G} 2-6,000$ cycles in water $\left(5^{\circ} \mathrm{C}-55^{\circ} \mathrm{C}-30\right.$ s); $\mathrm{G} 3-12,000$ cycles in water $\left(5^{\circ} \mathrm{C}-55^{\circ} \mathrm{C}-30\right.$ s). The samples were tested in a universal testing machine (EMIC) at a crosshead speed of $1 \mathrm{~mm} / \mathrm{min}$. Data were analyzed by ANOVA and Tukey tests. The results indicated that mean values of rupture tension (MPa) of G1 (10.71 \pm 3.54 ) did not differ statistically (p <5\%) from G2 (9.01 \pm 3.90), however there was statistical difference between G1 and G3 (7.28 \pm 3.00$)$. It was concluded that thermocycling significantly reduced the bond strength values when samples were submitted to 12,000 cycles.

Uniterms: Ceramics; Resin cements; Tensile strength.
\end{abstract}

\section{RESUMO}

$E$ Nobel-Biocare) e um cimento resinoso (Panavia F Kuraray CO). Nove blocos de cerâmica, com dimensões de 5x6x6mm, foram condicionados em uma de suas faces com o Sistema Rocatec (ESPE). A seguir foram cimentados a blocos de resina composta (Clearfil AP-X, Kuraray CO). Os conjuntos cerâmica-cimento-resina foram cortados em 75 corpos-de-prova com formato retangular com dimensões de 12x1x1mm e superfície adesiva apresentando $1 \mathrm{~mm}^{2} \pm 0,1 \mathrm{~mm}^{2}$. Os corpos-de-prova foram divididos em três grupos ( $n=25)$ : $\mathrm{G} 1$ - 14 dias em água destilada a $37^{\circ} \mathrm{C}, \mathrm{G} 2$ - 6000 ciclos em água $\left(5^{\circ} \mathrm{C}\right.$ e $\left.55^{\circ} \mathrm{C}\right)$ e $\mathrm{G} 3$ - 12000 ciclos em água $\left(5^{\circ} \mathrm{C}\right.$ e $55^{\circ} \mathrm{C}$ ). Os corpos-de-prova foram ensaiados sob velocidade de $1 \mathrm{~mm} / \mathrm{min}$ em máquina de ensaio universal (EMIC). Os dados foram tratados estatisticamente com os testes de Anova e Tukey e indicaram que os valores médios de tensão de rupturas $(\mathrm{MPa})$ de $\mathrm{G} 1(10,71 \pm 3,54)$ não diferiram estatisticamente $(\mathrm{p}<5 \%)$ de $\mathrm{G} 2(9,01 \pm 3,90)$, porém houve diferença significativa entre G1 e G3 (7,28 \pm 3,00). Concluiu-se que a ciclagem térmica diminuiu a resistência adesiva significativamente quando os corpos-de-prova foram submetidos a 12000 ciclos.

Unitermos: Cerâmica; Cimentos de resina; Resistência à tração. 


\section{INTRODUCTION}

Metal-ceramic fixed partial dentures (FPD) have been for many years used with satisfactory clinical results. However, some factors can compromise and limit its esthetic indications, as the presence of metallic framework, which demands an opaque application under the porcelain and removes the vitality aspect of the prostheses. Besides, the metallic cervical margins can provide a grayish area near to periodontal adjacent tissues, compromising the esthetic result of the rehabilitated dental element.

Nowadays, one of the ceramic systems that allows the making of FPD without metallic base is Procera AllCeram (Nobel Biocare) that uses the CAD-CAM technology (Computer Assisted Design - Computer Assisted Machining) to produce a framework constituted by sintered aluminum oxide densely compacted with $99.5 \%$ of purity. With this system, the ceramic framework can present values of flexural resistance close to 687MPa, providing favorable mechanical conditions to make unitary and fixed partial dentures, besides highly esthetic results ${ }^{11,29}$.

Adhesive resistance between conventional feldspathic ceramic and luting agents, mainly resin cements, is increased when the internal surface of prosthetic pieces is previously conditioned by acid etching following by application of a silane agent. The acid etching of those surfaces promotes a surface with micro-retentions and exhibition of silica crystals that, together with silanization, increase the chemical union with resin cements, resulting in elevated and stable values of adhesive union ${ }^{18,27}$.

On the other hand, the increase of alumina concentration in aluminous ceramic composition significantly reduces the silica content, making the conditioning procedures with acid substances contraindicated, because such procedure does not create micro-retentions as occurs with the feldsphatic porcelains ${ }^{3,16,20}$.

In this way, some researches tried to develop alternative methods to condition the surfaces of alumina ceramics in order to promote larger and stable values of adhesive union. One of those systems is Rocatec (ESPE), which promotes silica coating on the ceramic surface, allowing its adhesion to silane agents and resin cements.

In 1995, Kern and Thompson ${ }^{15}$ used the Rocatec system for the first time as an option to etch ceramic surfaces with high alumina concentrations, as In-Ceram system, creating a silica layer that presents larger affinity with the ceramic surface, silane agent and BIS-GMA resin cements. In the literature, there are few defined methods to treat the ceramic surface of Procera AllCeram system that provides clinically acceptable values of bond strength.

This study aimed at evaluating, using microtensile methodology, the thermal cycling effects on the bond strength between a resin luting cement containing phosphate monomer (Panavia F, Kuraray CO. - Japan) and the surface of an alumina ceramic conditioned with silica coating system (Rocatec).

\section{MATERIALAND METHODS}

Three blocks of alumina ceramic were used (Procera AllCeram) with dimensions of $15 \times 6 \times 6 \mathrm{~mm}$, obtained by CADCAM technology (Computer Assisted Design - Computer Assisted Machining) that makes frameworks constituted of sintered aluminum oxide. The production of the ceramic material is made by a scanner coupled to a computer that reads the surface of a matrix and develops a threedimensional draw. The images are sent by modem for Procera Sandvik AB, in Stockholm, Sweden, where the material is made. An acrylic block with dimensions of $15 \mathrm{~mm}$ of length, $6 \mathrm{~mm}$ of height and $6 \mathrm{~mm}$ of thickness was used as matrix to obtain the scanned images for Procera Scanner (Nobel Biocare).

As quality control, the ceramic blocks were radiogaphed to verify if there were bubbles inside them. The presence of bubbles led to disposal of the block.

Each ceramic block was split up, forming three small blocks with dimensions of 5x6x6mm each.

One of the faces of each ceramic block, with dimensions of $5 \times 6 \mathrm{~mm}$, was planed out with water sandpapers with granulation of $300,600,800,1000,1200$ to create a plane and uniform surface. Afterwards, each ceramic block was molded with addition silicone (Express - 3M Dental Products, St. Paul, MN - USA), in order to obtain an impression. This impression was used to make the blocks of resin composite (Clearfil AP-XTM, Kuraray CO. - Japan) that were used to allow construction of the specimen. The blocks of composite resin presented one of the faces with similar characteristics to the planed faces of the ceramic blocks, providing a good contact between them. After impression, the planed faces of the ceramic blocks were conditioned with Rocatec system (ESPE, Seefeld - Germany), that comprises initial sandblasting with $110 \mu \mathrm{m}$ aluminum oxide particles (RocatecPre), for 20 seconds with pressure of 2.8 bars, at a $10 \mathrm{~mm}$ standard distance perpendicular to the surface, followed by further sandblasting with $30 \mu \mathrm{m}$ silica particles (RocatecPlus), which promotes formation of the silica layer, and at last, application of the silane coating (Rocatec-Sil).

The ceramic blocks were cemented to the resin blocks with resin cement (Panavia F, Kuraray CO. - Japan), manipulated according to the manufacturer's recommendations and applied on the surface of the two blocks. The set was positioned in a device to promote cementation under a constant $750 \mathrm{~g}$ load for 10 minutes.

The excess cement was removed with an appropriate brush, followed by light curing (XL 3000 - 3M Dental Products, St. Paul, MN - USA), with a light intensity of $450 \mathrm{~mW} / \mathrm{cm}^{2}$. The light was applied for 40 seconds at each side of the set, followed by application of an oxygen inhibitor agent (Oxyguard, kuraray CO. - Japan), for 5 minutes on all faces. After curing of resin cement, the sets were washed with an air-water spray and stored in deionized water at $37^{\circ} \mathrm{C}$.

Nine sets of ceramic blocks cemented to resin blocks were obtained, which were fixed with cyanoacrylate in a lathe adapted by Andreatta et al ${ }^{1}$ to accomplish precision 
cuts with diamond disks measuring $0.15 \mathrm{~mm}$ in thickness and $22 \mathrm{~mm}$ in diameter.

The sets had $0.5 \mathrm{~mm}$ of their external aspects sectioned to eliminate cement excesses that could change the final bond strength values. Afterwards, the sets were cut in slices of $12 \times 6 \times 1 \mathrm{~mm}$ of area.

At last, each slice was fixed in the lathe for accomplishment of new cuts to obtain the samples.

From the nine sets of cemented blocks, 75 samples were randomly obtained with parallelogram form, with $12 \mathrm{~mm}$ of length and square transverse section with $1 \mathrm{~mm} \pm 0.01 \mathrm{~mm}^{2}$ of adhesive area. Three groups were established with 25 samples $(n=25)$ each, varying the type of thermal treatment. Group 1 was not thermocycled and the samples were stored for 14 days in deionized water at $37^{\circ} \mathrm{C}$. In Group 2, the samples were submitted to 6,000 thermal cycles in baths at $5^{\circ} \mathrm{C}$ and $55^{\circ} \mathrm{C}$, with 30 -second dwell times. In Group 3, the samples were thermocycled 12,000 times in baths at $5^{\circ} \mathrm{C}$ and $55^{\circ} \mathrm{C}$, with 30-second dwell times (Table 1).

After thermal treatments in a thermal cycling machine (Model 521-4D - Nova Ética Ind., Com. and Serv Ltda, São Paulo Vargem Grande - SP, Brazil), each sample was fixed with cyanoacrylate sticker (Super Bonder) to the modified caliper for accomplishment of microtensile tests. In this method, the applied force is perpendicular to the long axis of the specimen, avoiding strain forces and shear of the adhesive area. Each sample fixed to the caliper was adapted to the universal testing machine (DL-1000, EMIC Equipments and Systems Ltda, São José dos Pinhais - PR, Brazil) and loaded to failure under tension at a crosshead speed of $1.0 \mathrm{~mm} /$ minute. After testing, the fracture modes of each sample were determined by examination in a stereoscopic microscope at 18x magnification (Tecnival Carl Zeiss - JENA).

TABLE 1- Groups and thermocycling treatments

\begin{tabular}{lcl}
\hline Group & $\begin{array}{l}\text { Number of } \\
\text { samples }\end{array}$ & Thermocycling \\
\hline G1 & 25 & $\begin{array}{l}\text { Stored for } 14 \text { days in } \\
\text { deionized water at } 37^{\circ} \mathrm{C} \\
6,000 \text { cycles } / 5-55^{\circ} \mathrm{C}-30 \mathrm{~s} \\
\text { G2 }\end{array}$ \\
G3 & 25 & 12,000 cycles $/ 5-55^{\circ} \mathrm{C}-30 \mathrm{~s}$ \\
\hline
\end{tabular}

\section{Statistical analysis}

The data (MPa) were statistically tested to verify the differences between groups. Anova and Tukey tests at 0.05 of significance were used.

\section{RESULTS}

The means and standard deviations of bond strength data (MPa) obtained in the microtensile test are presented in Table 2.

It was verified that standard deviation values were close and did not statistically differ (Bartlet test: $\mathrm{X}^{2}=1.61$; $\mathrm{df}=2 ; \mathrm{p}$ $=0.446>0.05$ ).

The data were analyzed by one-way ANOVA, at $\alpha=0.05$. This parametric test indicated that the bond strength values had significant difference between experimental groups (ANOVA, $\mathrm{F}_{\mathrm{df}(2 ; 72)}=5.99 ; \mathrm{p}=0.004<0.05$ ).

Tukey test $(\alpha=0.05)$ showed that the bond strength mean of group $1(10.71 \pm 3.54)$ was statistically higher $(\mathrm{p}<0.05)$ than group 3 (7.28 \pm 3.00$)$. Bond strength mean of Group 2 (9.01 \pm 3.90$)$ did not differ from group 1 and group 3 .

Regarding the fracture modes, all samples showed adhesive failures when observed at 18x magnification in stereoscopic microscope.

\section{DISCUSSION}

Nearly one decade after its development, the microtensile methodology is still researched with the purpose of determining a pattern of specimen dimensions. In that way, based on studies of Sano, et al. ${ }^{22}$ (1994); Shono, et al. ${ }^{23}$ (1997); Bianchi ${ }^{4}$ (1999); Pashley, et al. ${ }^{21}$ (1999); Shono, et al. ${ }^{24}$ (1999), Della Bona, et al. ${ }^{8}$ (2000), microtensile methodology was used to make specimens with transverse section areas of approximately $1 \mathrm{~mm}^{2}$, fixed in the test device (caliper) with cyanoacrylate adhesive.

In the present study, methods of superficial conditioning were not compared, because the study was based on studies that reported more efficient results for conditioning of the alumina surface with sandblasting, mainly with aluminum oxides and silica, because those promoted larger values of adhesive resistance than the acid conditioning used in conventional feldspathic ceramics.

Kraivixien-Vongphantuest, et al. ${ }^{16}$ (1992) and Kern and

TABLE 2- Descriptive statistics (mean, standard deviation and coefficient of variation) for data (MPa) obtained in the microtensile test

\begin{tabular}{lccc}
\hline Statistics & No thermocycling & $\begin{array}{c}\text { Groups } \\
\mathbf{6 , 0 0 0} \text { cycles }\end{array}$ & $\mathbf{1 2 , 0 0 0 \text { cycles }}$ \\
\hline Mean $(\mathrm{MPa})$ & 10.71 & 9.01 & 7.28 \\
SD & 3.54 & 3.90 & 3.00 \\
CV $(\%)$ & 33.05 & 43.33 & 41.29 \\
\hline
\end{tabular}


Thompson ${ }^{13-4}$ (1994) reported that the adhesive union between resin cements and the In-Ceram surface was not appropriate when acid etching and silanization were performed, because the acids do not provide formation of micro retentions similar to those that occur in conventional feldspathic ceramics ${ }^{7,27}$

Some authors ${ }^{15,20}$ suggested conditioning with $110 \mu \mathrm{m}$ aluminum oxide sandblasting $\left(\mathrm{Al}_{2} \mathrm{O}_{3}\right)$ to create micro retentions in the surface of the alumina ceramic; however, it was verified that only with that conditioning there is no chemical union with the silanization agents, due to the low amount of silica present in the glass of In-Ceram ceramic matrix ${ }^{13-4}$.

Even though those conditioning methods presented a high value of adhesive resistance immediately after cementation procedures when submitted to thermal cycling or even under storage in larger periods than thirty days in distilled water at $37^{\circ} \mathrm{C}$, the values of adhesive resistance decreased at very low levels, not promoting a stable union between ceramic and cement.

The Rocatec-ESPE system, used to condition metallic surfaces with good results of adhesive union ${ }^{12}$, was initially used by Kraivixien-Vongphantuset, et al. ${ }^{16}$ (1992) and Neikes, et al. ${ }^{19}$ (1992) and later by Kern and Thompson ${ }^{13-4}(1994,1995)$ to condition the surfaces of alumina ceramic (In-Ceram), promoting the increase of silica content to $19.7 \%$ in weight by the tribochemical covering of the ceramic surface. That conditioning method, according to those authors' results, presented bonding values larger than other adhesive methods of superficial conditioning, besides a stable adhesive union between ceramic and BIS-GMA resin cements.

The adhesive union between resin cement and phosphate monomer (Panavia F) and the surface of the In-Ceram ceramic conditioned with the Rocatec system was evaluated by Soares, et al. ${ }^{25}$ (2002). This study showed values significantly greater than the association of that cement with surfaces sandblasted only with $110 \mu \mathrm{m}$ aluminum oxide; however, the effect of thermal cycling was not evaluated . Andreatta, et al. ${ }^{2}$ (2002), Galhano, et al. ${ }^{10}$ (2002), evaluating the effect of 1,500 thermal cycles on the adhesive union between surfaces of InCeram conditioned with silica coatings (Cojet and Rocatec systems) and Panavia F resin cement, obtained similar results with stable adhesive union, even after thermal cycling.

Although for the In-Ceram alumina ceramic the combination of superficial treatment with silica covering (Rocatec) and resin cement (BIS-GMA) has promoted a satisfactory and durable adhesive union, Friederich and Kern ${ }^{9}$ (2002) reported that, under the thermal cycling effect, the adhesive union between Procera AllCeram's surface conditioned with Rocatec system and a resin cement (BISGMA) was not stable. In that same study, higher values of adhesive resistance were obtained for the group in which the resin cement containing phosphate monomer (Panavia 21 EX) was used with Procera AllCeram's surface conditioned with aluminum oxide sandblasting $(110 \mu \mathrm{m})$. The authors attributed the higher values of that group to the differences in the processes to make the ceramic, because for the Procera AllCeram system the glass infiltration is not performed as for the In-Ceram system, and the glass infiltration could be necessary for formation of the silica layer by sandblasting with Rocatec system.

Blixt, et al. ${ }^{5}$ (2000) obtained favorable results of adhesive union associating conditioning of Procera AllCeram's surface with the Rocatec system and resin cement (BIS-GMA); however, the storage and thermal cycling effect was not verified.

Regarding the conditioning of Procera AllCeram surface with acids, Awliya, et al. ${ }^{3}$ (1998) verified that this method, in agreement with studies of Madani, et al. ${ }^{18}$ (2000), did not increase the values of adhesive union. With scanning electron microscope, the authors verified that Procera AllCeram's surface after conditioning with hydrofluoric acid (9.6\%) maintained the same morphological structure.

However, studies were not found in the literature that evaluated the thermal cycling effect on the adhesive union between resin cement containing phosphate monomer (Panavia F) and the surface of Procera AllCeram ceramic conditioned with the Rocatec system.

Based on Leibrock et al. ${ }^{17}$ (1999), 6,000 and 12,000 thermal cycles were used between 5 and $55^{\circ} \mathrm{C}$, that is similar, in physiologic normal conditions, approximately to the period of five and ten years, respectively.

The results of the present study demonstrated that thermal cycling negatively influenced the quality of adhesive resistance, promoting the decrease in union values when the number of thermal cycles was increased.

The negative effect of thermal cycling on the adhesive union can be explained by the fact that materials with different lineal thermal expansion coefficients (LTEC) also presented different degrees of shrinkage and expansion. That process promotes the fatigue phenomenon of the materials, leading to rupture of the union between them ${ }^{6}$. The LTEC of conventional resins ranges from 25 to $35 \times 10^{-6} \mathrm{~K}^{-1}$, and for alumina ceramics this value is approximately $6.6 \times 10^{-6} \mathrm{~K}^{-1}$. Therefore, the effects of temperature variations when those two materials are associated can lead to fatigue of the adhesive union.

According to Söderholm and Roberts ${ }^{26}$ (1990), Wegner et al. ${ }^{28}$ (2002), the storage in water and thermal cycling can alter the properties of resin materials, because they contain components (matrix and inorganic particles) with different LTEC and can suffer fatigue under thermal variations that accelerate their structural weakness, promoting union flaws.

Another factor that might have contributed to the decrease in the adhesive resistance values was the sample dimension that had a small area, receiving larger influence of thermal cycling effects on its surface. Shono, et al. ${ }^{24}$ (1999) verified that adhesive unions in samples with different dimensions presented reductions of bond strength in samples with small areas, after similar periods of storage and thermal cycling.

It should be considered that the methodology and the variables in the present study did not simulate all clinical conditions happening in masticating physiologic processes. It is believed that the use of traditional adhesive resistance data should be restricted to comparison of effects from properties and microstructure of materials and from treatment conditions that could improve the fracture resistance, and 
not to accomplish categorical clinical interpretations about resistance union.

\section{CONCLUSION}

With the results of this study, it can be concluded that thermal cycling with 6,000 cycles did not influence the resistance values of the adhesive union between aluminous ceramic (Procera AllCeram) conditioned with Rocatec System and resin cement (Panavia-F). However, 12,000 thermal cycles significantly decrease the adhesive resistance in relation to the group that has not been submitted to thermal cycling.

\section{REFERENCES}

1- Andreatta Filho OD, Nishioka RS, Almeida EES. Construção de um torno mecânico para realizar preparos dentais padronizados, [resumo I047]. Pesqui Odontol Bras 2000; 14(supl):17 [apresentado na $17^{\text {a }}$ Reunião SBPqO].

2- Andreatta Filho OD, Araújo MAJ, Nishioka RS, Leite FPP, Dias AHM, Souza FA, Giannini V. Efeito da ciclagem térmica sobre a resistência adesiva entre uma cerâmica aluminizada e um cimento resinoso, [resumo Pb250]. Pesqui Odontol Bras 2002; 16 (supl):200 [apresentado na $19^{\mathrm{a}}$ Reunião SBPqO].

3- Awliya W, Oden A, Yaman P, Dennison JB, Razzoog ME. Shear bond strength of a resin cement to densely sintered high-purity alumina with various surface conditions. Acta Odontol Scand 1998 Feb;56(1):9-13.

4- Bianchi J. Estudo sobre a resistência à microtração em função das dimensões, módulo de preensão e formato do corpo de prova. São Paulo; 1999.112f. [Tese de Doutorado em Odontologia - Faculdade de Odontologia da Universidade de São Paulo, São Paulo].

5- Blixt M, Adamczak E, Linden LA, Oden A, Arvidson K. Bonding to densely sintered alumina surfaces: effect of sandblasting and silica coating on shear bond strength of luting cements. Int J Prosthodont 2000 May/Jun;13(3):221-6.

6- Craig RG, Peyton FA. Physical and mechanical properties. In: Restorative dental materials. 5. ed. St. Louis: Mosby; 1975. cap3, p.48-63.

7- Della Bona A, Anusavice KJ, Hood JA. Effect of ceramic surface treatment on tensile bond strength to a resin cement. Int J Prosthodont 2002 May/Jun;15(3):248-53.

8- Della Bona A, Anusavice KJ, Shen C. Microtensile strength of composite bonded to hot-pressed ceramics. J Adhes Dent 2000 Winter; 2(4):305-13.

9- Friederich R, Kern M. Resin bond strength to densely sintered alumina ceramic. Int J Prosthodont 2002 Jul-Aug;15(4):333-8.

10- Galhano GAP, Kimpara ET, Andreatta Filho OD, Siqueira LO, Camargo FP, Travassos AC. Avaliação da resistência adesiva entre uma cerâmica aluminizada e um cimento resinoso submetidos à ciclagem térmica, [resumo Ib176]. Pesqui Odontol Bras 2002; 16(supl):83 [apresentado na $19^{\mathrm{a}}$ Reunião SBPqO].

11- Itinoche MK. Estudo da influência da ciclagem mecânica na resistência à flexão de cerâmicas. São José dos Campos; 2002. 110f. [Tese de Doutorado em Odontologia, Área de Concentração em Prótese - Faculdade de Odontologia de São José dos Campos, Universidade Estadual Paulista].
12- Kern M, Thompson VP. Influence of prolonged thermal cycling and water storage on the tensile bond strength of composite to $\mathrm{NiCr}$ alloy. Dent Mater 1994 Jan;10(1):19-25.

13- Kern M, Thompson VP. Sandblasting and silica coating of a glassinfiltrated alumina ceramic: volume loss, morphology, and changes in the surface composition. J Prosthet Dent 1994 May; 71(5):453-61.

14- Kern M, Thompson VP. ESCA surface characterization of the alumina ceramic In-Ceram after vafrious conditioning methods for resin bonding, [abstract 763]. J Dent Res 1994; 73 (sp. issue): 197.

15- Kern M, Thompson VP. Bonding to glass infiltrated alumina ceramic: adhesive methods and their durability. J Prosthet Dent 1995 Mar;73(3):240-9.

16- Kraivixien-Vongphantuset R. Bond strengh no resin cement to InCeram core material, [abstract 141]. J Dent Res 1992; 71(sp. issue): 533.

17- Leibrock A, Degenhart M, Behr M, Rosentritt M, Handel G. In vitro study of the effect of thermo- and load-cycling on the bond strength of porcelain repair systems. J Oral Rehabil 1999 Feb;26(2):1307.

18- Madani M, Chu FC, McDonald AV, Smales RJ. Effects of surface treatments on shear bond strengths between a resin cement and an alumina core. J Prosthet Dent 2000 Jun;83(6):644-7.

19- Neikes MJ, Kern M, Strub JR. Tensile bond strength of two silicoating (silicate/silanization) systems on the $\mathrm{AL}_{2} \mathrm{O}_{3}$-Ceramic In-Ceram, [abstract 144]. J Dent Res 1992; 71(sp. Issue): 533.

20- Ozcan M, Alkumru HN, Gemalmaz D. The effect of surface treatment on the shear bond strength of luting cement to a glassinfiltrated alumina ceramic. Int J Prosthodont 2001 Jul/Aug;14(4):3359

21- Pashley DH, Carvalho RM, Sano H, Nakajima M, Yoshiyama M, Shono Y, et al. The microtensile bond test: a review. J Adhes Dent 1999 Winter;1(4):299-309. Review.

22- Sano H, Shono T, Sonoda H, Takatsu T, Ciucchi B, Carvalho R, et al. Relationship between surface area for adhesion and tensile bond strength-evaluation of a micro-tensile bond test. Dent Mater 1994 Jul; 10(4):236-40.

23- Shono Y, Terashita M, Pashley EL, Brewer PD, Pashley DH. Effects of cross-sectional area on resin-enamel tensile bond strength. Dent Mater 1997 Sep;13(5):290-6.

24- Shono Y, Terashita M, Shimada J, Kozono Y, Carvalho RM, Russell CM, et al. Durability of resin-dentin bonds. J Adhes Dent 1999 Autumn; 1(3):211-8.

25- Soares LF, Neisser MP, Mallmann A, Oyafuso DK, Carvalho MCA, Costa EMV, Nishioka RS. Microtração de cerâmica aluminizada e cimento resinoso: efeito do tratamento da superfície cerâmica, [resumo Pa217]. Pesqui Odontol Bras 2002; 16 (supl):149 [apresentado na 19a Reunião SBPqO].

26- Söderholm KJ, Roberts MJ. Influence of water exposure on the tensile strength of composites. J Dent Res 1990 Dec; 69(12):1812-6.

27- Stangel I, Nathanson D, Hsu CS. Shear strength of the composite bond to etched porcelain. J Dent Res 1987 Sep; 66(9):1460-5.

28- Wegner SM, Gerdes W, Kern M. Effect of different artificial aging conditions on ceramic-composite bond strength. Int J Prosthodont 2002 May-Jun;15(3):267-72.

29- Zeng K, Oden A, Rowcliffe D. Flexure tests on dental ceramics. Int J Prosthodont 1996 Sep-Oct;9(5):434-9. 